\title{
Rozwijanie języka edukacji szkolnej na przykładzie streszczenia
}

\author{
Developing the language of school education \\ as exemplified by a summary
}

\begin{abstract}
Su m mary: The author of the article defines school communicative situation as the one requiring from the student an ability to use specialised language known as the language of school education. According to regulations currently in force, improving the fluency in the said language is a task of teachers of all school subject because knowing it is one of the conditions of attaining educational success. The article presents a proposal to work on a summary that includes the determinants of school education language.
\end{abstract}

Keywords: language of school education, summary, language education, teaching language

Dla każdego ucznia i każdej uczennicy przekroczenie progu szkoły to bardzo ważny moment. Wraz z uczniami do nowej szkoły, nowej klasy wkracza ich dom: kapitał, który z niego wynoszą. Niektóre elementy tego domowego zaplecza można zobaczyć gołym okiem, a niektóre, i to one staną się podstawą zaprezentowanej tu analizy, usłyszeć. Na temat relacji między kapitałem językowym a pochodzeniem społecznym, od lat pięćdziesiątych XX wieku, kiedy swoje badania przedstawił Basil Bernstein ${ }^{1}$, napisano już bardzo wiele i w bardzo róż-

1 B. Bernstein: Some Sociological Determinations of Perceptions. „British Journal of Sociology” 1958, vol. 9, s. 159-174; Idem: Language and Social Class. „British Journal of Sociology" 1960, vol. 11, s. 271-276; Idem: Odtwarzanie kultury. Oprac. A. Piotrowski. Przeł. Z. Bokszański i A. Piotrowski. Warszawa 1990. 
nych kontekstach ${ }^{2}$. Jest to także obserwacja, której niemal bezwiednie dokonuje każdy nauczyciel poznający swoich nowych uczniów. Dziecko nie przychodzi zatem do szkoły jako „niezapisana tablica”, a to, co jest na niej zapisane, ma wpływ na to, jak się odnajdzie w nowej sytuacji komunikacyjnej, w której język potrzebny jest do innych celów. Poziom językowy ucznia wpływa na jego karierę edukacyjną od samego początku, a różnice w językowych zasobach nie są łatwe do zniwelowania.

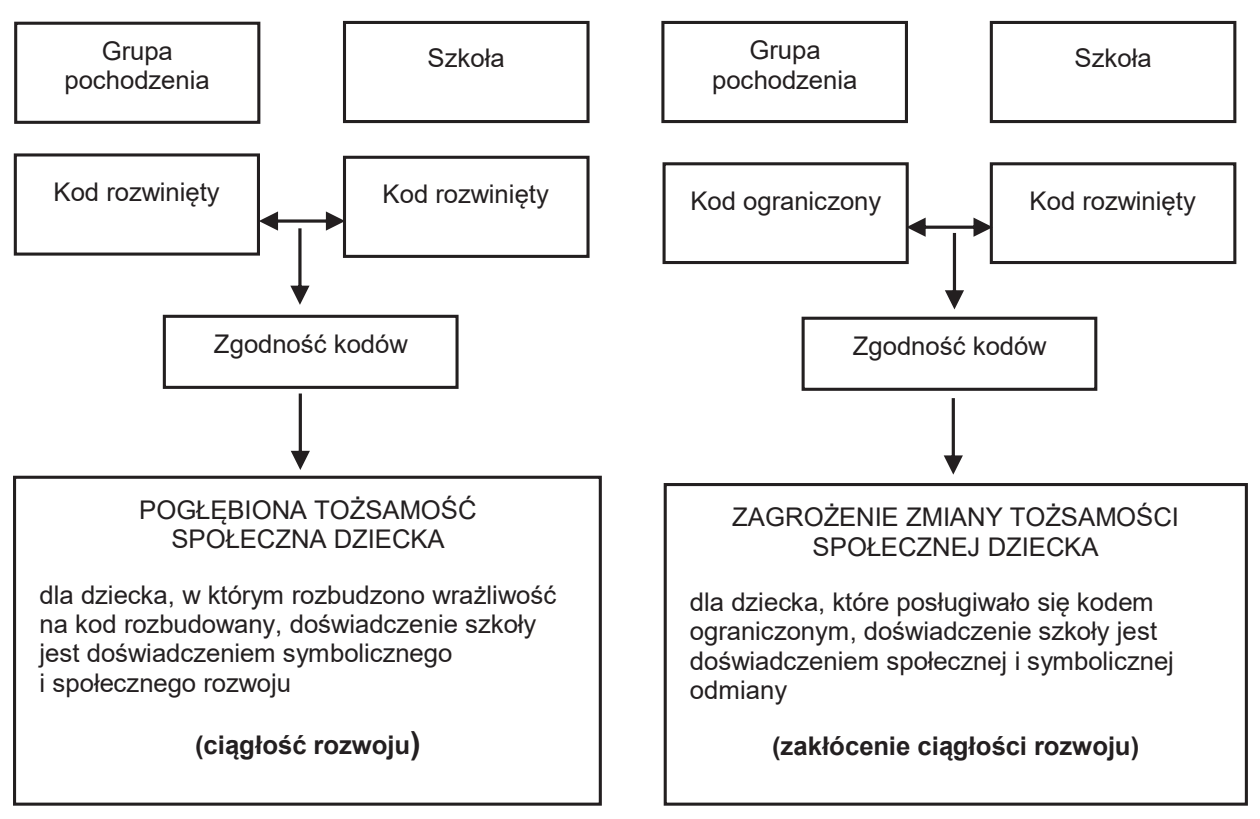

Schemat 1. Konsekwencje relacji pomiędzy kodami komunikacji szkoły i grupy społecznej, z której wywodzi się dziecko ${ }^{3}$

Schemat 1. pokazuje, jakie konsekwencje dla rozwoju dziecka ma jedna ważna zmienna - poziom rozwoju językowego. To stopień opanowania języka pozwala uczennicom i uczniom odczuć zmianę związaną z rozpoczęciem szkol-

${ }^{2}$ Zob. np. W. Labov: The Social Stratification of English in New York City. Washington 1966. Por. Idem: Sociolinguistic Patterns. Philadelphia 1972; D. Hymes: Ethnography, Linguistics, Narrative Inequality. London 1996; L. Milroy: Language and Social Networks. Oxford 1980; K. Ożóg: Polszczyzna młodzieży — kod ograniczony i kod rozwinięty pochodna postawy mieć i postawy być. W: Czynności tworzenia i rozumienia wypowiedzi. Red. J. Porayski-Pomsta. Warszawa 2002, s. 13-23; M. Trysińska: Kod rozwinięty i kod ograniczony w filmach animowanych dla dzieci. W: Wiedza o języku i kompetencje językowe uczniów. Red. B. Niesporek-Szamburska. Katowice 2012, s. 151-174.

${ }^{3}$ E. Filipiak: Człowiek - język - rzeczywistość (w kontekście pytań o efektywna edukację językowa w szkole, s. 8. https://repozytorium.ukw.edu.pl/bitstream/handle/item/1818/Ewa\%20Fili piak\%20Cz\%C5\%82owiek\%20jezyk\%20rzeczywistosc.pdf?sequence=1 [datadostępu:23.03.2020]. 
nej edukacji jako kolejny etap rozwoju lub przeciwnie, stanowić barierę, która nie pozwala poczuć się w szkole jak u siebie.

Taki swoisty szok językowy niektórzy uczniowie i niektóre uczennice przeżywają w szkole dwukrotnie: pierwszy raz, gdy rozpoczynają edukację szkolną (czasem może to także dotyczyć przedszkola), a drugi — kiedy przechodzą do klasy IV, w której zmianie ulega sposób organizacji pracy.

Nie jest zatem zaskoczeniem, że praca nad językiem uczniów stanowi jedno z ważnych zadań projektowanego procesu edukacyjnego. We wstępie do podstawy programowej do języka polskiego dla klas IV_-VIII czytamy: „Zakres znajomości języka ojczystego i sprawność w posługiwaniu się nim ułatwia przyswajanie wiedzy z innych dziedzin (przedmiotów) i jest dla każdego ucznia podstawą sukcesu szkolnego"4. Przywołany fragment wyraźnie wskazuje, że to język właśnie, poziom jego znajomości, jest ważnym środkiem służącym osiągnięciu sukcesu edukacyjnego. Tak wyrażony cel nauczania zostaje jeszcze wzmocniony i przeniesiony w obszar zobowiązań nauczycieli wszystkich przedmiotów, nie tylko języka polskiego:

Rozwijanie umiejętności posługiwania się językiem polskim w mowie i w piśmie, w tym dbałość o wzbogacanie zasobu słownictwa uczniów oraz przestrzeganie przez nich norm poprawnościowych, należy do obowiązków nauczycieli wszystkich przedmiotów ${ }^{5}$.

Te dwa przywołane fragmenty podstawy programowej stanowią wystarczającą podstawę do postawienia tezy, że praca nad specyficzną, charakterystyczną dla szkolnej edukacji odmianą języka/stylu ${ }^{6}$ jest jednym z najważniejszych zadań szkoły, a opanowanie tego sposobu komunikowania/komunikowania się — środkiem do osiągnięcia sukcesu edukacyjnego.

W latach siedemdziesiątych XX wieku Jim Cummins na podstawie badań dotyczących dwujęzyczności i obserwacji uczenia się języka drugiego ${ }^{7}$ zaproponował podział znajomości języka na dwa poziomy: BICS (basic interpersonal communicative skills), czyli podstawowy system komunikacji interpersonalnej, i CALP (cognitive academic language proficiency), czyli zaawansowany po-

${ }^{4} \mathrm{https} / / /$ podstawaprogramowa.pl/Szkola-podstawowa-IV-VIII/Jezyk-polski [data dostępu: 23.03.2020].

5 Ibidem.

${ }^{6} \mathrm{~W}$ dalszej części tekstu zawsze będzie już mowa o języku. Umieszczenie tu alternatywy język/styl jest świadectwem świadomości braku precyzji wskazanej przez K. Bakułę, choć z powodów objaśnionych później wątpliwości te nie zostały uwzględnione. Por. K. Bakuła: Mówione zpisane: komunikacja, język, tekst. Wrocław 2008, s. 32-38.

7 W rozumieniu zaproponowanym przez W.T. Miodunkę. Por. W.T. Miodunka: Polszczyzna jako język drugi. Definicja języka drugiego. W: Silva rerum philologicarum. Studia ofiarowane Profesor Marii Strycharskiej-Brzezinie z okazji Jej jubileuszu. Red. J.S. Gruchała, H. Kurek. Kraków 2010, s. 240-241. 
znawczo język dyskursu edukacyjnego. Podstawowy system komunikacji interpersonalnej (BICS) uczniowie opanują szybciej. To język związany z codzienną komunikacją, mocno osadzony w kontekście, z którym uczniowie przychodzą do szkoły. Także ten poziom opanowania języka wymaga pracy, wzbogacania słownictwa, ćwiczenia umiejętności „odczytywania” sytuacji komunikacyjnej i dopasowywania do niej komunikatu ${ }^{8}$. Rozwijanie zaawansowanego poznawczo języka dyskursu edukacyjnego to zadanie dla edukacji. Praca nad używaniem języka w kontekstach typowych dla szkoły wymaga od ucznia znacznie większego wysiłku poznawczego, ponieważ jest on nie tylko znacznie trudniejszy, ale także ograniczony kontekstowo. Uczący się mają przed sobą zadania wymagające mobilizacji z jednej strony zasobów językowych, a z drugiej wiedzy oraz innych umiejętności. Miejsce kontekstu w rozumieniu wypowiedzi tworzonych w obydwu wspomnianych odmianach języka obrazuje schemat 2.

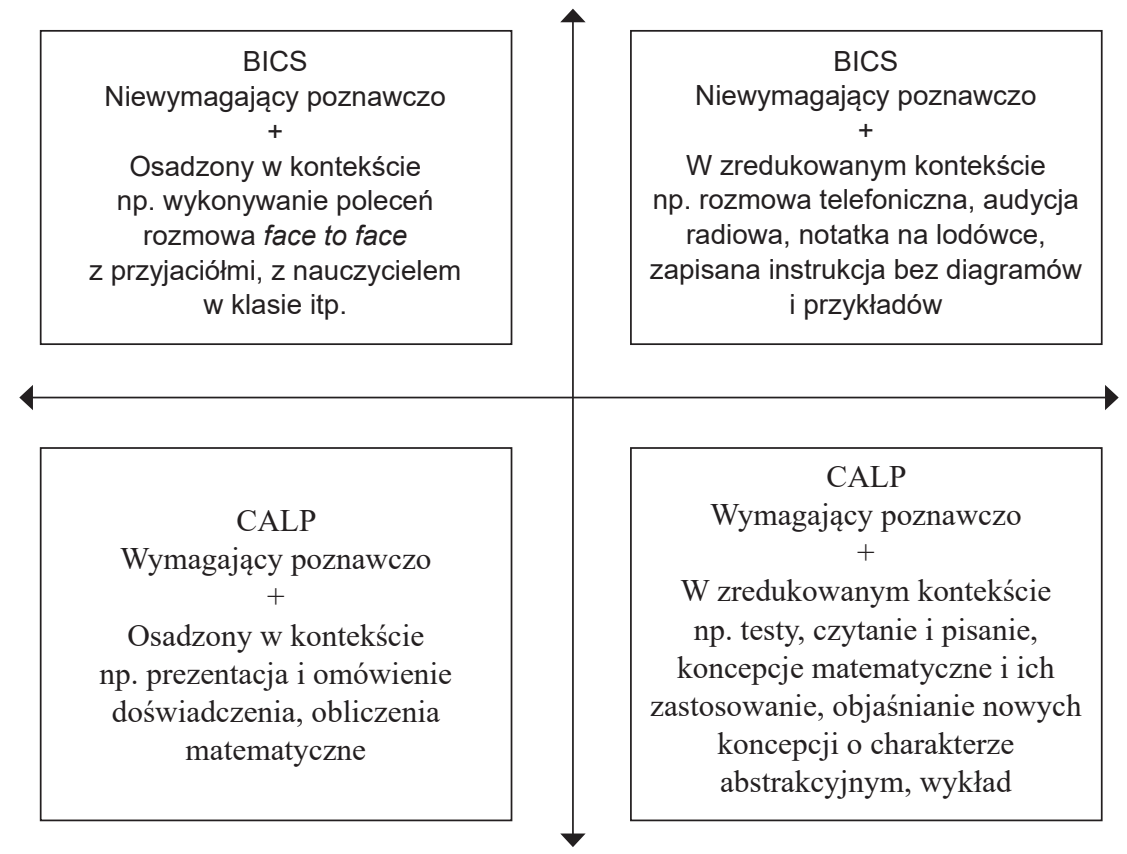

Schemat 2. Użycie języka a kontekst ${ }^{9}$

${ }^{8} \mathrm{~W}$ polskiej szkole od lat dziewięćdziesiątych XX wieku postuluje się (z różnym skutkiem) wprowadzanie koncepcji komunikacyjnej w kształceniu językowym w opozycji, czy jako uzupełnienie, edukacji językowej opartej na przekazywaniu wiedzy na temat struktur językowych. Problemem tym nie będę się tutaj szczegółowo zajmować. Został on już opisany w wielu pracach. Por. np. M. Szymańska: Między nauka o języku a rozwijaniem języka. Koncepcje ksztatcenia językowego na przełomie XX i XXI wieku. Kraków 2016. Tam także obszerna bibliografia.

${ }^{9}$ Na podstawie Four Quadrants of the BICS/CALP Spectrum. W: K.M. Lillyw hite: Developing Cognitive Academic Language Proficiency (CALP) in Diverse Classrooms. Utah 2011, s. 36. 
Użycie języka do celów związanych z uczeniem się różni się zatem od używania języka wyłącznie w funkcji komunikacyjnej. Osłabiona zostaje przede wszystkim rola kontekstu, w tym także niewerbalnych środków komunikowania, które mogą znacząco ułatwiać porozumienie. Dwie ważne szkolne sytuacje komunikacyjne - uczenie się/zdobywanie wiedzy i informowanie o tym, co się już umie - wiążą się z użyciem języka w sytuacji zredukowanego kontekstu, co z kolei wymaga korzystania ze struktur umożliwiających nie tylko precyzyjne przekazywanie informacji, ale także nazywanie relacji, porządkowanie $\mathrm{i}$ argumentowanie, wnioskowanie itd. Mamy tu zatem do czynienia z językiem dopasowanym do szkolnej sytuacji komunikacyjnej, w literaturze nazywanym też językiem edukacji szkolnej.

Termin język edukacji szkolnej jest stosunkowo nowy w polskiej dydaktyce. W oczywisty sposób wiąże się z procesami uczenia się i nauczania zachodzącymi w szkole. W literaturze anglojęzycznej i francuskojęzycznej używa się terminów language of schooling, academic language lub langue de scolarisation, langue de l'école ${ }^{10}$. Terminy te nie są tożsame, ale często stosowane są zamiennie ${ }^{11}$. Szerokie rozumienie terminu zaproponowała Mary J. Schleppegrell: język edukacji szkolnej to język, którym uczniowie posługują się w szkole do zdobywania wiedzy i umiejętności ${ }^{12}$.

Dla większości dzieci rozpoczęcie nauki w szkole oznacza konfrontację z nowymi sposobami wykorzystywania języka. Sposoby te obejmują używanie języka do wykonywania nowych rodzajów zadań i realizacji nowych oczekiwań dotyczących tego, w jaki sposób zbudowana zostanie wypowiedź. Przebywanie w szkole, uczenie się, wiąże się z nowymi rodzajami interakcji, w których uczniowie zobowiązani są często do podawania informacji, które w codziennym kontekście można uznać za coś oczywistego, a także szczegółowego określania relacji między pojęciami. Ponadto oczekuje się, że uczniowie zaczną używać języka w nowy sposób, pisząc, co niesie ze sobą nowe sposoby organizacji treści. Te nowe sposoby

https://digitalcommons.usu.edu/cgi/viewcontent.cgi?article=1086\&context=honors [data dostępu: 23.03.2020].

${ }^{10}$ Por. m.in. J. Cummins: BICS and CALP: Empirical and Theoretical Status of the Distinction. In: Encyclopaedia of Language and Education. Eds. B. Street, N.H. Hornberger. New York 2008; M.J. Schlep pegrell: Academic Language in Teaching and Learning: Introduction to the Special Issue. „The Elementary School Journal” 2012, no. 112 (3), s. 409_418; J.-C. B e a c co, M. Byram, M. Cavalli, D. Coste et al.: Guide pour le développement et la mise en cuvre de curriculums pour une éducation plurilingue et interculturelle. [B.m.w.] 2016.

${ }^{11}$ We wszystkich przywołanych nazwach pojawia się ,język” jako element składowy, stąd decyzja o przyjęciu terminu ,język edukacji szkolnej” mimo zastrzeżeń o mnożeniu różnych języków zgłaszanych m.in. przez K. Bakułę.

12 „The language used in school to help students acquire and use knowledge”. M.J. Schleppegrell: Academic Language..., s. 419. 
tworzenia znaczeń umożliwiają uczestnictwo w szerszym zakresie zadań i kontekstów, dlatego ważne jest, aby wszyscy uczniowie mieli możliwość rozwijania swojego potencjału językowego w miarę postępów w nauce ${ }^{13}$.

Tym, co odróżnia język codziennej komunikacji od języka edukacji szkolnej, jest przede wszystkim jego funkcja, zadania, jakie powinny być możliwe do wykonania przy jego użyciu, np.:

- informowanie: przekształcenie informacji podanych przez nauczyciela/ tekst; opowiadanie ,własnymi słowami”;

— porównywanie: opisywanie podobieństw/różnic między obiektami, pomysłami...

— porządkowanie: sekwencji obiektów, pomysłów, wydarzeń...;

- klasyfikowanie: grupowanie obiektów, pomysłów według określonych cech;

- analizowanie: dzielenie całości na części, identyfikowanie relacji lub modeli;

- wnioskowanie: formułowanie wniosków, hipotez, przewidywanie konsekwencji;

— ocenianie i perswadowanie: określanie powodów działania, decyzji, punktów widzenia;

- rozwiązywanie problemów: definiowanie/prezentowanie problemów, ustalanie rozwiązań;

- syntetyzowanie: grupowanie, integrowanie w całość;

- ewaluacja: ocena i weryfikacja wartości obiektu, pomysłu, decyzji...

Oczywiście, także w codziennej komunikacji może zachodzić konieczność użycia języka do osiągnięcia podobnych celów, jednak wymagany poziom precyzji wypowiedzi oraz możliwość wykorzystania środków pozajęzykowych są znacząco inne. Cechy języka edukacji szkolnej najwyraźniej dają się zaobserwować na dwóch poziomach: leksykalnym i składniowym. Elementami odróżniającymi język edukacji szkolnej od języka komunikacji, a zbliżającymi go do języka i stylu naukowego są:

- postawa mówiących — język edukacji szkolnej bliski jest stylowi oficjalnemu, akcentuje dystans mówiącego do odbiorcy i przekazywanych treści;

${ }^{13}$ For the majority of children, starting school means confronting new ways of using language. These include using language to accomplish new types of tasks and new expectations for how they will structure what they say. Schooling brings new kinds of interaction, where students are often required to state information that in an everyday context could be taken for granted, and to specify relationships between concepts in some detail. In addition, students are expected to begin using language in a new mode, writing, which brings with it new ways of grammatical organization. These new ways of meaning-making enable participation in a wider range of tasks and contexts, so it is important that all students have opportunities to develop their language potential as they progress in schooling". M.J. Schleppegrell: The Language of Schooling. A Functional Linguistics Perspective. London 2004, s. 21. 
— nasycenie informacyjne tekstów — język edukacji szkolnej pojawia się zazwyczaj w tekstach dotyczących tematów abstrakcyjnych, które prezentowane są w sposób zwięzły i możliwie jednoznaczny;

— układ (kompozycja) informacji — teksty charakteryzują się specjalnym uporządkowaniem, akcentującym logikę wywodu; przeważają zdania wielokrotnie złożone (często podrzędnie), w których strukturze pojawiają się wskaźniki nawiązania i zespolenia rzadko występujące w języku codziennej komunikacji: takie jak: tym samym..., z uwagi na..., ze względu na...; występują także typowe dla dydaktycznej odmiany języka naukowego gatunki;

- dobór słownictwa - teksty charakteryzuje duże zróżnicowanie leksykalne, dominują w nich wyrazy abstrakcyjne, terminy specyficzne dla danej dziedziny oraz terminy ogólnoakademickie;

— kongruencja (zgodność) przedstawieniowa — w języku edukacji szkolnej często używane są tzw. metafory gramatyczne ${ }^{14}$, silnie związane z nominalizacją struktur składniowych, która powoduje nasycenie przekazu informacjami;

- prezentacja przekazu w oderwaniu od kontekstu ${ }^{15}$.

W szkole materializacją języka edukacji są teksty podręcznikowe, a także wymagania, jakie stawia się językowi wypowiedzi uczniów i nauczycieli. Stanisław Gajda klasyfikuje podręcznik szkolny jako gatunek, podlegający rygorom stylu naukowego w jego odmianie dydaktycznej ${ }^{16}$. Zdaniem Jolanty Nocoń,

Styl podręcznika szkolnego i w ogóle postać językowa każdego tekstu edukacyjnego kształtują się w specyficznej sytuacji konfliktu. Z jednej strony w szkole przekazywana jest naukowa, a nie potoczna wiedza o świecie, co wymaga użycia odpowiedniego języka-narzędzia; z drugiej — odbiorca-uczeń to osoba, którą charakteryzują istotne ograniczenia kompetencyjne

${ }_{14}$ Według M.A.K Hallidaya, metafora gramatyczna jest jedną $\mathrm{z}$ najważniejszych cech dyskursów akademickich, urzędowych i naukowych. Porównując dwa wypowiedzenia o tym samym znaczeniu: Ponieważ technologia jest coraz lepsza, ludzie sa w stanie podróżować coraz szybciej i Postęp w technologii umożliwia coraz szybsze podróżowanie, zauważymy, w jaki sposób sensy wywiedzione z doświadczenia i logiki stają się bardziej metaforyczne. Coraz lepsza (technologia) i podróżować w kolejnym zdaniu stają się rzeczownikami; empiryczne znaczenie "spakowane” zostaje do grup nominalnych, zanika także koniunkcja wyrażona spójnikiem podrzędności ponieważ. Dla języka edukacji szkolnej charakterystyczne będzie zatem używanie rzeczowników w odniesieniu do procesu (w mniej formalnej komunikacji są to czasowniki) czy rzeczowników w odniesieniu do jakości (w mniej formalnej komunikacji są to przymiotniki); w funkcji podmiotu pojawiają się często także rzeczowniki abstrakcyjne.

${ }_{15}$ Na podstawie C.E. Snow, P. Uccelli: The Challenge of Academic Language. In: The Cambridge Handbook of Literacy. Eds. D.R. Ols on, N. Torrance. Cambridge 2009, s. 119-120.

${ }^{16}$ S. Gajda: Podstawy badań stylistycznych nad językiem naukowym. Warszawa-Wrocław 1982. 
(poznawcze i komunikacyjnojęzykowe), i język nauki niekoniecznie może być tu najtrafniejszym nośnikiem treści [...].

Autor tekstu dydaktycznego jest zatem zmuszony szukać kompromisowego sposobu językowo-stylowej realizacji tekstu i odpowiedzieć sobie na podstawowe pytanie: na ile możliwe jest posłużenie się rejestrem naukowym, a w jakim stopniu musi on zostać zastąpiony innym rejestrem języka (ogólnym lub popularnonaukowym) po to, by przekaz nie okazał się niekomunikatywny? [...] I jeszcze jeden czynnik utrudniający autorowi podręcznika zadanie: tekst dydaktyczny w swym kształcie językowym powinien także stymulować rozwój kompetencji językowej ucznia, nie może więc być mowy o całkowitym dostosowaniu się do poziomu języka ucznia, ale jedynie o nieprzekraczaniu bariery, poza którą tekst traci sens dla odbiorcy ${ }^{17}$.

Ponieważ to podręcznik, a także wypowiedzi, które powstają na lekcji (pod kierunkiem nauczyciela), stanowią dla uczniów wzorzec do naśladowania, oczywiste jest, że język edukacji szkolnej i jego rozwijanie powinno się znajdować w centrum uwagi na wszystkich lekcjach. Jest to perspektywa nauczania ważna dla wszystkich uczniów, choć znacznie ważniejsza dla posługujących się kodem ograniczonym.

Jako przykład planowych działań, mających na celu pracę nad rozwijaniem języka edukacji szkolnej, przedstawiony zostanie fragment cyklu lekcji zaprojektowanych wokół tematu Stworzenie świata, który został przeprowadzony w klasie V. Uczniowie zapoznawali się z różnymi tekstami objaśniającymi pochodzenie świata, odpowiadającymi na pytanie Skąd się wziąt świat?. Wśród tekstów o charakterze mitycznym znalazł się również taki, który odpowiadał na postawione wcześniej pytanie, korzystając z ustaleń nauki. Przygotowaniem do rozmowy było krótkie zadanie domowe: „Poszukajcie w Internecie informacji na temat Wielkiego Wybuchu”. Polecenie zostało wykonane, uczniowie posiadali notatki na zadany temat, choć, co nie było specjalnym zaskoczeniem, wszystkie informacje pochodziły z Wikipedii. Klasowa rozmowa toczyła się wokół opowiadania o wydarzeniu. Uczniowie zastanawiali się, czy to możliwe, czy są na to jakieś dowody, czy to tylko jeszcze jeden mit. Ujawniły się także problemy słownikowe: większość klasy nie wiedziała, jakie znaczenie ma przymiotnik „skondensowany”. Wspólnie poszukiwaliśmy znaczenia w internetowym słowniku języka polskiego i wtedy okazało się, że niektórzy zetknęli się z tym słowem jako określeniem mleka sprzedawanego w puszce. W każdym razie słowo nie należało do czynnego słownika uczniów, wymagało dodatkowych działań, które prowadziłyby do stworzenia połączeń między tym, co nowe, i tym, co od

17 J. Nocoń: Podręcznik szkolny $w$ dyskursie dydaktycznym - tradycja i zmiana. Opole 2009 , s. $53-54$. 
dawna w użyciu. W tym celu wybraliśmy technikę porównania. Technika ta, z której często korzystaliśmy na lekcjach, polega na zbudowaniu porównania $\mathrm{z}$ użyciem nowego słowa ${ }^{18}$. Kiedy uczniowie czytali swoje propozycje, okazało się, że skojarzenia prawie całej klasy są wyjątkowo „deserowe”. Tylko dwoje uczniów z doświadczeniem migracji miało inne propozycje. Zapamiętywanie wzmocniliśmy także, gromadząc znane już uczniom synonimy: zagęszczony, gęsty, skupiony, zbity, stężony... Każdy z uczniów mógł zaproponować własny graficzny zapis informacji lub dodać ilustrację.

Po takim przygotowaniu można już było przejść do tekstu o Wielkim Wybuchu ${ }^{19}$.

\section{Wielki Wybuch}

Uczeni twierdzą, że przed wieloma miliardami lat miał się zdarzyć WIELKI WYBUCH, czyli gigantyczna eksplozja. Świat był wtedy jak niewyobrażalnie małe i niewyobrażalnie ciężkie ziarenko, które nagle i z wielką gwałtownością rozerwało się. Z niego powstały galaktyki, rozprysły się jak odłamki po wybuchu granatu i do dziś jeszcze rozbiegają się na wszystkie strony. Tę nieustającą ucieczkę galaktyk jako pierwszy zauważył Edwin Hubble na początku XX wieku. Trzeba tu jednak dodać, że nie wszyscy uczeni uznają teorię Wielkiego Wybuchu za prawdziwą. W każdym razie niedawno, dzięki bardzo precyzyjnemu teleskopowi, noszącemu imię Hubble'a, na Ziemię dotarły niesamowite obrazy z Kosmosu. Kamery teleskopu wyniesione poza Ziemię rejestrują dramatyczne spektakle zderzenia galaktyk przechodzących jedna przez drugą jak olbrzymie potwory z miliardów gwiazd, fale szoku rozchodzące się w przestrzeni po eksplozji gwiazdy supernowej, gorące wnętrza mgławicy, gdzie z pyłu i gazu tworzą się na naszych oczach nowe gwiazdy.

Zderzające się galaktyki widzimy takimi, jakimi były bardzo, bardzo dawno temu, bo dzieli je od nas odległość kilkuset milionów lat świetlnych. Najdalsze zaś galaktyki, do których sięgnął kosmiczny teleskop, stanowią absolutne wyzwanie dla naszej wyobraźni - są bowiem obrazem sprzed około czternastu miliardów lat. Tyle czasu potrzebowało ich światło, żeby do nas dotrzeć, pokonując trzysta tysięcy kilometrów w każdej sekundzie.

${ }_{18}$ Zob. także R.J. Marzano, D.J. Pickering: Building Academic Vocabulary. Teachers Manual. Alexandria, Virginia, 2005. Por. M. Pamuła-Behrens, M. Szymańska: Metodyka nauczania języka edukacji szkolnej uczniów z doświadczeniem migracji. Metoda JES-PL — matematyka. Kraków 2018 http://fundacjareja.eu/do-pobrania/ [dostęp: 19.04.2020].

${ }_{19}$ M. Jędrychowska, Z.A. Kłakówna: To lubię! Teksty i zadania. Podręcznik do języka polskiego dla klasy 5. Książka ucznia. Kraków 1995, s. 102-103. 
Dzięki teleskopowi Hubble'a uczeni oglądają więcej, niż są w stanie zrozumieć i zobaczyć.

Pierwsze spotkanie z tekstem miało charakter głośnego czytania przez nauczyciela. Samodzielnemu, cichemu czytaniu uczniowskiemu towarzyszyło podkreślanie niezrozumiałego słownictwa. Wyjaśnialiśmy je wspólnie, najpierw posiłkując się wiedzą uczniów, a dopiero gdy sobie nie poradziliśmy, korzystaliśmy ze źródeł internetowych, używając smartfonów. Uczniowie sami wybierali słowa, które miały zostać objaśnione w zeszycie. Do zapisu stosowali techniki znane z poprzednich lekcji: synonimy, krótkie objaśnienia, ilustracje. Tylko uczniowie z doświadczeniem migracji dokładali do prowadzonych na bieżąco słowniczków kolejne karty „tropiciela słówek" ${ }^{20}$. Jednego tylko nie trzeba było tłumaczyć — wielbiciele „Gwiezdnych wojen” doskonale wiedzieli, co to są lata świetlne.

Wspólną pracę nad redagowaniem streszczenia poprzedziło zadanie kontrolne. Aby się przekonać, jak uczniowie bez pomocy poradzą sobie z wybieraniem i porządkowaniem informacji, poprosiłam ich o skrócenie tekstu o Wielkim Wybuchu tak, aby zawierał najważniejsze informacje. W efekcie powstało 25 tekstów, które pokazały różne kompetencje uczniów klasy V w zakresie tworzenia streszczenia. Uczniowie nie mieli w zasadzie problemu z wyborem informacji. Znakomita większość z nich ujęła w swoich propozycjach informacje: - o Wielkim Wybuchu jako eksplozji, która miała miejsce bardzo dawno temu (np. Przed miliardami lat miat być Wielki Wybuch, czyli ogromne BUM; Kilka miliardów lat temu byt WIELKI WYBUCH! Uczeni mówia, że byt jak GIGANTYCZNA EKSPLOZJA!; Uczeni twierdza, że miliardy lat temu byta ogromna eksplozja ${ }^{21}$ ), choć niektórzy tylko nieznacznie skrócili zdanie z oryginału (np. Przed wieloma miliardami lat miat się zdarzyć Wielki Wybuch; [...] że przed miliardami lat miał być Wielki Wybuch) lub zmienili jego szyk (Wielki Wybuch stać się miat przed miliardami lat);

— o uczonych jako źródle tych informacji: naukowcy mówia, uczeni myśla, wedtug uczonych, uczeni przypuszczaja, uczeni uważaja, a także powtórzone za tekstem uczeni twierdza;

— o wielkości świata przed wybuchem (Świat, który wybucht, byt maty i cięż$k i$; Wtedy jeszcze świat byt mały, skondensowany i goracy; Przed wybuchem

${ }^{20}$ M. Pamuła-Behrens, M. Szymańska: $W$ polskiej szkole. Materiały do pracy z uczniami z doświadczeniem migracji. Przewodnik. Kraków 2017. https://www.ore.edu.pl/wp-content/ plugins/download-attachments/includes/download.php?id=16877 [data dostępu: 4.04.2020]. Por. M. Pamuła-Behrens, M. Szymańska: W polskiej szkole. Materiały do pracy z uczniami z doświadczeniem migracji. Kraków 2017. http://fundacjareja.eu/w-polskiej-szkole/ [data dostępu: 4.04.2020].

${ }^{21}$ Wszystkie fragmenty tekstów uczniowskich zostały poprawione pod względem ortograficznym. 
świat byt niewiarygodnie mały, ciężki i goracy; Minimalny świat wybucht). Większość uczniów postanowiła jednak wykorzystać porównanie do ziarenka, modyfikując lub po prostu przepisując zdanie z tekstu. Niektórzy zdecydowali się zamienić w porównaniu ziarenko na kamień (Świat byt malutki i ciężki jak kamień);

- o wątpliwościach niektórych badaczy (Nie wszyscy uczeni myśla, że Wielki Wybuch jest prawda; Nie wszyscy naukowcy się zgadzaja z Wielkim Wybuchem; Nie wszyscy podzielali jego [Hubble'a] teorię; Niektórzy uczeni wątpili w Wielki Wybuch); choć zdarzyło się, że uczniowie przepisali zdanie $\mathrm{z}$ tekstu (Nie wszyscy naukowcy uznaja tę teorie);

- o zasługach Edwina Hubble'a (Jako pierwszy zauważyt to Edwin Hubble; Edwin Hubble w XX wieku zauważyt rozszerzajaca się galaktykę; Edwin Hubble jako pierwszy odkryt tę nieustająca ucieczkę galaktyk; Tę ucieczkę galaktyk pierwszy zauważyt Edwin Hubble w XX wieku), ale w wielu przypadkach uczniowie wyraźnie wykorzystywali konstrukcje z tekstu;

- o informacjach otrzymanych za pomocą teleskopu. W tym przypadku uczniowie skracali fragment tekstu opisujący wygląd kosmicznej przestrzeni przekazany przez teleskop, zwykle jednak przepisywali przynajmniej jeden element (Teleskop zarejestrowat dramatyczne spektakle, np. zderzenia galaktyk; Teleskop pokazuje trudne do wyobrażenia galaktyki). Zdarzyły się jednak wypowiedzi, których autorzy podjęli próbę oderwania się od streszczanego oryginału (Dzięki teleskopowi Hubble'a dotarty do nas widoki zderzeń galaktyk i tworzenia nowych gwiazd; Dzięki teleskopowi Hubble'a możemy zaobserwować zdarzenia dziejace się miliardy lat temu; Dzięki precyzyjnemu teleskopowi Hubble’a można zobaczyć przeróżne obrazy kosmo$s u$ ). Bardzo wielu uczniów przepisało ostatnie zdanie, tylko nieznacznie je modyfikując (Dzięki teleskopowi uczeni dostrzegaja więcej, niż moga wyttumaczyć).

Jeśli chodzi o strukturę składniową analizowanych tekstów, przeważają $\mathrm{w}$ nich zdania pojedyncze oraz zdania złożone podrzędnie, składające się z dwóch zdań. Relacja między składnikami najczęściej wybierana przez uczniów to rozwijanie informacji sygnalizowanej przez zdanie nadrzędne w zdaniu podrzędnym przydawkowym (Świat byt malutki i ciężki jak kamień, który nagle eksploduje). W wielu tekstach ta sama informacja wywoływała jednocześnie użycie tej samej konstrukcji składniowej, np.: uczeni jako źródło wiedzy — zdanie złożone podrzędnie ze zdaniem dopełnieniowym (Uczeni/Naukowcy mówia/ myśla $\dot{z} e . .$.$) ; wątpliwości niektórych badaczy — zdanie złożone współrzędnie$ przeciwstawne ([...] ale nie wszyscy [...]).

Oczywiście, w zbiorze wszystkich tekstów, jakie przygotowali piątoklasiści, można znaleźć wiele różnych realizacji. Jedni uczniowie bardzo dobrze poradzili sobie z zadaniem, inni mieli problemy ze zbudowaniem spójnej wypowie- 
dzi, byli też tacy, którzy będą wymagali dużego wsparcia. Oto trzy wybrane przykłady:

Przykład 1.

Gigantyczna eksplozja, czyli Wielki Wybuch, stać się miat przed miliardami lat. Najpierw świat byt bardzo maty $i$ skondensowany. Nagle minimalny świat wybucht, a potem powstaly galaktyki.

Skutki Wielkiego Wybuchu pierwszy zauwazyt Edwin Hubble, ale nie wszyscy podzielali jego teorię.

$W$ następnym dziesięcioleciu watpliwości zostały rozwiane, dzięki teleskopowi noszacemu imię Hubble'a, który zarejestrowat dramatyczne spektakle, takie jak np. zderzenia galaktyk.

Dzięki teleskopowi Hubble’a możemy spróbować opisać poczatek świata.

Przykład 2.

Kilka miliardów lat temu był Wielki Wybuch! Uczeni mówia, że byt jak gigantyczna eksplozja!

Jako pierwszy zauważyt to Edwin Hubble. Żyt on na poczatku XX wieku. Niedawno, dzięki teleskopowi Hubble'a, na Ziemię dotarty obrazy z kosmosu. Kamery teleskopu zarejestrowaty, jak z pytu i gazu tworza się nowe gwiazdy. Od innych galaktyk dzieli nas kilkaset milionów lat świetlnych.

Dzięki teleskopowi uczeni moga nam więcej wyttumaczyć.

Przykład 3.

Świat przed eksplozja byt jak ciężkie ziarenko. Było tak goraco, że rozerwało się ziarenko i z rozerwanego ziarenka wyszly galaktyki. Edwin Hubble żyt w XX wieku. Zauważyt ucieczke galaktyki. Niedawno wybudowano teleskop Hubble'a. Nie wszyscy wierzyli w Wielki Wybuch. Z kosmosu przystano obrazy z teleskopu Hubble'a.

W każdym z przywołanych tekstów można wskazać mocniejsze i słabsze elementy, analizować je na co najmniej kilku płaszczyznach. Kiedy jednak przyjrzymy się uczniowskiemu wyborowi środków składniowych, zauważymy, że:

— w przykładzie pierwszym konstrukcja zdań wspiera łączenie informacji i wskazywanie relacji między nimi;

— w przykładzie drugim dominują zdania pojedyncze; jedyne zdanie złożone odwołuje się wprost do fragmentu oryginalnego tekstu, ale informacje w nim zawarte zostały dość sprawnie przekształcone;

— w przykładzie trzecim mamy do czynienia z zapisem tego, jak uczeń myśli, najpierw zapisując potok składniowy, a następnie dzieląc poznane informa- 
cje na krótkie odcinki, które układa w kolejności zaproponowanej w tekście podstawowym.

Analiza uczniowskich realizacji zadania pokazała konieczność pracy nad szeroko rozumianymi kompetencjami językowymi, w tym nad językiem edukacji szkolnej.

Rozmowę o tekście rozpoczęliśmy od rekonstrukcji sytuacji komunikacyjnej: kto, do kogo, w jakiej sytuacji i dlaczego właśnie w taki sposób mówi? Propozycje były różne. Uczniowie dyskutowali, posiłkując się fragmentami tekstu, aby przekonać tych, którzy pomyśleli inaczej. Zgodziliśmy się na rekonstrukcję, którą przedstawia schemat 3 .

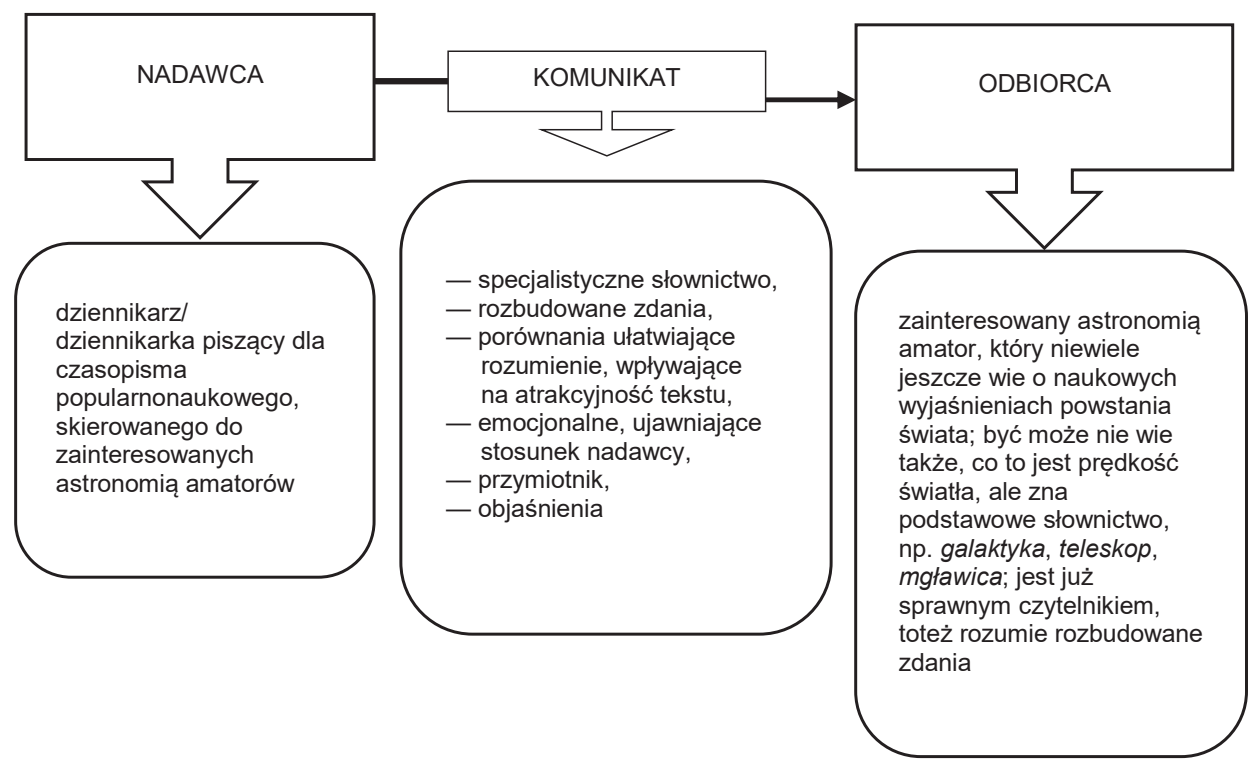

Schemat 3. Rekonstrukcja sytuacji komunikacyjnej

Szczególnie ważna, z punktu widzenia celów lekcji, była analiza językowa. W V klasie uczniowie nie mają odpowiedniego metajęzyka do nazwania konstrukcji składniowych charakterystycznych dla czytanego tekstu (zdanie złożone, zdanie złożone współrzędnie/podrzędnie, typy zdań złożonych i ich funkcje, imiesłowowy równoważnik zdania itp.). Rozmowa była swego rodzaju walką z ograniczeniami języka, brakiem precyzyjnych terminów, które pozwoliłyby na skrócenie dyskusji i większą precyzję. Wnioski, do jakich doszliśmy, były z konieczności dość powierzchowne: długie zdania składające się z wielu części, dużo przecinków, wyliczenia, jedno zdanie przynosi dłuższą opowieść, w zdaniach można znaleźć różne zależności, poszczególne części dużego zdania jakoś od siebie zależą itp. Lepiej uczniowie poradzili sobie ze środkami wpływa- 
jącymi na obrazowość. Z łatwością wskazywali porównania (świat jak ziarenko; galaktyki jak potwory), nagromadzenie epitetów (niewyobrażalnie mate i niewyobrażalnie ciężkie ziarenko; gorace wnętrza mgławicy; olbrzymie potwory), rozbudowane obrazy (wybuchajace galaktyki, które jak odtamki granatu rozpryskuja się w przestrzeni; galaktyki walczace ze soba jak potwory z gwiazd). Zastanawiali się, co najlepiej nadawałoby się na ilustrację i dlaczego. Końcowy wniosek brzmiał: tekst jest barwny, działa na wyobraźnię, pozwala lepiej zrozumieć opisywane zjawisko komuś, kto o nim nie słyszał. Co jednak stałoby się z tekstem, gdyby zmieniła się sytuacja komunikacyjna? Jak wyglądałby komunikat, gdyby nadawcą był astronom, który jest przekonany, że Wielki Wybuch miał miejsce, a odbiorcą inny astronom? Uczniowie jeszcze raz, w niewielkich grupach, przyglądali się tekstowi, wykreślając z niego te fragmenty, które wydawały im się nie pasować do zarysowanej sytuacji. Wszyscy zgodnie, choć z żalem, wykreślili porównania i rozbudowane obrazy, zostawiając nieco epitetów. Usunęli także wszystkie te elementy, które wyrażały wątpliwość (miat się zdarzyć; nie wszyscy uczeni uznają teorię). Pozostawione zostały wszystkie specjalistyczne terminy, a wykreślone objaśnienia (np. informacja o prędkości światła). Okazało się, że z pierwotnego tekstu zostało niewiele — skondensowane, konkretne fakty. Efektem wspólnej pracy był następujący, dyskutowany i zapisywany na tablicy zdanie po zdaniu, tekst:

Przed miliardami lat nastąpił Wielki Wybuch. Skondensowany świat eksplodował. Galaktyki oddaliły się od siebie. W XX wieku dostrzegł to Edwin Hubble. Teleskop Hubble'a dostarczył na Ziemię dowody. Pochodziły one sprzed miliardów lat. Pokazywały zderzenia galaktyk, wybuchy supernowych, rozgrzewanie się mgławic i powstawanie nowych gwiazd.

Następnie zastanawialiśmy się, czym charakteryzuje się tekst, który powstał na lekcji. Jaka jest relacja między oryginałem a tym, co zaproponowali uczniowie. Znów pomocne okazało się słowo, które sprawiło im trudność na samym początku — ,skondensowany”. Co do tego nie było żadnych wątpliwości nasz tekst jest bardziej skondensowany. To był moment, kiedy pojawił się właściwy termin określający tę relację między dwoma tekstami - streszczenie. Ale nasze streszczenie nie było jeszcze gotowe. Przypomnieliśmy sobie strukturę składniową tekstu oryginału i postanowiliśmy jeszcze nad naszą wersją popracować. Chodziło o skonstruowanie takich zdań, aby wskazywały one różne wewnętrzne relacje, np. wynikanie, następstwo czasu, dopełnianie/dopowiadanie. Oto kolejna wersja:

Przed miliardami lat nastąpił Wielki Wybuch, w wyniku którego skondensowany świat eksplodował, a galaktyki oddaliły się od siebie. W XX wieku dostrzegł to Edwin Hubble. Teleskop, noszący jego imię, dostarczył na 
Ziemię, pochodzące sprzed miliardów lat, dowody na zderzenia galaktyk, wybuchy supernowych, rozgrzewanie się mgławic i powstawanie nowych gwiazd.

Celem lekcji było przygotowanie streszczenia tekstu popularnonaukowego tak, aby spełniało ono kryteria stylu naukowego: użycie słownictwa specjalistycznego oraz złożonych konstrukcji składniowych, które mogłyby unieść ciężar relacji między zamkniętymi w zdaniach sensami. Czy to się udało osiągnąć? Na pewno mogliśmy skonfrontować dwa teksty realizujące różne funkcje. Jeden informował, ale także oddziaływał na wyobraźnię, objaśniał, odwoływał się do wiedzy czytelnika. Drugi skupiał się na informacji i opierał się na założeniu, że czytelnik wie, o czym czyta. Obydwa wymagały od odbiorcy sprawności w czytaniu.

Jeśli przyjrzymy się typowym szkolnym praktykom, z pewnością zauważymy, że redagowanie streszczenia w sposób zaplanowany, oparty nie tylko na intuicji uczniów, dokonuje się głównie na lekcjach języka polskiego, mimo że umiejętność streszczania (nie zawsze na piśmie) wykorzystywana, a tym samym oczekiwana, jest na lekcjach wszystkich przedmiotów szkolnych. Uczniowie wykonują zadania, które wymagają od nich wyboru najważniejszych informacji, notowania, skrótowego opisywania procesów i zjawisk z użyciem precyzyjnego, uwzględniającego relacje i związki języka, który ma także cechy języka specjalistycznego na poziomie leksyki. Celowy wydaje się zatem postulat, aby (zgodnie z obowiązującą podstawą programową) nauczyciele organizowali zaplanowane ćwiczenia, które służyłyby rozwijaniu języka uczniów w zakresie umożliwiającym im sprawne komunikowanie się (w tym także prezentowanie własnej wiedzy i umiejętności) w sytuacjach typowych dla kontekstu edukacyjnego. Taką funkcję spełnia właśnie język edukacji szkolnej.

\section{Bibliografia}

Bakuła K.: Mówione $\approx$ pisane: komunikacja, język, tekst. Wrocław 2008.

Beacco J.-C., Byram M., Cavalli M., Coste D. et al.: Guide pour le développement et la mise en œuvre de curriculums pour une éducation plurilingue et interculturelle. [B.m.w.] 2016.

Bernstein B.: Language and Social Class. „British Journal of Sociology” 1960, vol. 11, s. $271-$ 276.

Bernstein B.: Odtwarzanie kultury. Oprac. A. Piotrowski. Przeł. Z. Bokszański i A. Piotrowski. Warszawa 1990.

Bernstein B.: Some Sociological Determinations of Perceptions. „British Journal of Sociology” 1958, vol. 9, s. 159-174. 
Cummins J.: BICS and CALP: Empirical and Theoretical Status of the Distinction. In: Encyclopaedia of Language and Education. Eds. B. Street, N.H. Hornberger. New York 2008.

Gajda S.: Podstawy badań stylistycznych nad językiem naukowym. Warszawa-Wrocław 1982.

Hymes D.: Ethnography, Linguistics, Narrative Inequality. London 1996.

Jędrychowska M., Kłakówna Z.A.: To lubię! Teksty i zadania. Podręcznik do języka polskiego dla klasy 5. Ksiązka ucznia. Kraków 1995.

Labov W.: The Social Stratification of English in New York City. Washington 1966.

Labov W.: Sociolinguistic Patterns. Philadelphia 1972.

Marzano R.J., Pickering D.J.: Building Academic Vocabulary. Teachers Manual. Alexandria, Virginia, 2005.

Milroy L.: Language and Social Networks. Oxford 1980.

Miodunka W.T.: Polszczyzna jako język drugi. Definicja języka drugiego. W: Silva rerum philologicarum. Studia ofiarowane Profesor Marii Strycharskiej-Brzezinie z okazji Jej jubileuszu. Red. J.S. Gruchała, H. Kurek. Kraków 2010.

Nocoń J.: Podręcznik szkolny w dyskursie dydaktycznym — tradycja i zmiana. Opole 2009.

Ożóg K.: Polszczyzna młodzieży — kod ograniczony i kod rozwinięty pochodna postawy mieć i postawy być. W: Czynności tworzenia i rozumienia wypowiedzi. Red. J. Porayski-Pomsta. Warszawa 2002.

Schleppegrell M.J.: Academic Language in Teaching and Learning: Introduction to the Special Issue. „The Elementary School Journal” 2012, no. 112 (3), s. 409-418.

Schleppegrell M.J.: The Language of Schooling. A Functional Linguistics Perspective. London 2004.

Snow C.E., Uccelli P.: The Challenge of Academic Language. In: The Cambridge Handbook of Literacy. Eds. D.R. Olson, N. Torrance. Cambridge 2009.

Szymańska M.: Między nauka o języku a rozwijaniem języka. Koncepcje kształcenia językowego na przełomie XX i XXI wieku. Kraków 2016.

Trysińska M. Kod rozwinięty i kod ograniczony w filmach animowanych dla dzieci. W: Wiedza o języku i kompetencje językowe uczniów. Red. B. Nies porek-Szamburska. Katowice 2012.

\section{Źródła internetowe}

Filipiak E. Człowiek — język-rzeczywistość (w kontekście pytań o efektywna edukację językowa $w$ szkole. https://repozytorium.ukw.edu.pl/bitstream/handle/item/1818/Ewa\%20Filipiak\%20 Cz\%C5\%82owiek\%20jezyk\%20rzeczywistosc.pdf?sequence=1 [data dostępu: 23.03.2020].

https://podstawaprogramowa.pl/Szkola-podstawowa-IV-VIII/Jezyk-polski [data dostępu: 23.03.2020].

Lillywhite K.M.: Developing Cognitive Academic Language Proficiency (CALP) in Diverse Classrooms. Utah 2011. https://digitalcommons.usu.edu/cgi/viewcontent.cgi?article=1086\& context=honors [data dostępu: 23.03.2020].

Pamuła-Behrens M., Szymańska M.: Metodyka nauczania języka edukacji szkolnej uczniów $z$ doświadczeniem migracji. Metoda JES-PL - matematyka. Kraków 2018. http://fundacjareja. eu/do-pobrania/ [data dostępu: 23.03.2020].

Pamuła-Behrens M., Szymańska M.: W polskiej szkole. Materiały do pracy z uczniami z doświadczeniem migracji. Przewodnik. Kraków 2017. https://www.ore.edu.pl/wp-content/plugins/ download-attachments/includes/download.php?id=16877 [data dostępu: 23.03.2020].

Pamuła-Behrens M., Szymańska M.: W polskiej szkole. Materiały do pracy z uczniami z doświadczeniem migracji. Kraków 2017. http://fundacjareja.eu/w-polskiej-szkole/ [data dostępu: 23.03.2020]. 